\title{
Milk Fatty Acids Profile and the Impact on Human Health
}

\author{
Santin Junior IA, Silva KCC and Cucco DC* \\ Department of Zootecnia, Santa Catarina State University, Brazil
}

Submission: January 28, 2019; Published: February 14, 2019

*Corresponding author: Cucco DC, Department of Zootecnia, Santa Catarina State University, Brazil

\begin{abstract}
Milk fat is the component that shows major sensitivity to modification through animal feed, which allows to manipulate the fatty acids profile. This review approached the milk fatty acids composition, physiological mechanisms and dietary modifications that may lead to changes in the fatty acids profile and their influence on human health. The proportions of saturated fatty acids (SFA) and polyunsaturated fatty acids (PUFA) on milk have variations that are associated with many factors and their interactions. In the rumen, the microorganisms promote changes in the diet fatty acid profile through biohydrogenation, factor that may difficult the study of different nutritional management in the final product composition, and because that, studies should match the lipid profile with the ruminal microbiota arrangement. In the mammary gland, fat formation is a complex process which milk fatty acids are derived from "de novo" synthesis in epithelial cells and from long chain fatty acids arising from diet and adipose tissue mobilization, the last one in negative energy balance. For beneficial effects on human health, a lower n-6: n-3 ratio may reduce the risk of coronary artery disease. Future studies may continue including modifications in the fatty acid profile using different diets, but at a molecular level and with effects on gene expression of enzymes involved in the milk fat formation process. In addition, animals genetic manipulation and selection to obtain products with desired specific composition may be more deepen in the next studies.
\end{abstract}

Keywords: Biohydrogenation; Nutritional handling; Genetic selection

Abbreviations: SFA: Saturated Fatty Acids; PUFA: Polyunsaturated Fatty Acids; MUFA: Monounsaturated Fatty Acids; CLA: Conjugated Linoleic Acid; VFA: Volatile Fatty Acids; NEB: Negative Energy Balance; LDL: Low-Density Lipoprotein; HDL: High-Density Lipoprotein

\section{Introduction}

The continuous increase of the world population has resulted in higher cow's milk consumption, which explain the annual per capita consumption parameter of 284.5 liters of milk equivalent on USA [1] and 111.4 of world average [2]. In addition to the demand for quantity, the consumers are paying more attention to the organic milk, as well as for milk and derived products with greater concentrations of desirable fatty acids, which would make them healthier $[3,4]$. In the last 20 to 25 years many researchers have compared the nutrient concentrations of milk, studying the possibilities and limitations resulting of cow's diet manipulation, however, the great majority focused on fat composition $[4,5]$. This is due to the milk fat sensibility to modifications through diets be higher than the protein or lactose's sensibility, which allow to manipulate the fatty acids profile by feeding the animals with different nutrients sources [5]. According to Jenkins \& McGuire [5], the amount of fat which could be modified around 3 percentage points, while the protein content in 0.5 and the lactose, in turn, cannot be manipulated through diet, except when used extreme and not usual diets. Moreover, there are changes in this proportions during the lactation and according to the milk composition of the livestock breeds.
Considering the significant variations on milk fat content and composition due to changes on diet, this review's purpose was to evaluate the milk fatty acids profile, the physiological mechanisms that could lead to changes in this profile and its influence on human health. In order to review scientific articles published in recent years, from authors that, through animals' diet modifications, attempted to manipulate the milk fatty acids profile.

\section{Overall Composition of Milk Fatty Acids}

The milk fat is composed by $98 \%$ of triglycerides, $1 \%$ phospholipids and $0.5 \%$ of sterols, which around $70 \%$ are saturated fatty acids (SFA) and the proportion of polyunsaturated (PUFA) and $\mathrm{C} 18: 2$ and $\mathrm{C} 18: 3$ range from $3 \%$ to $1 \%$ in relation to the amount of total lipids [6]. Data that agree with the nutritional composition of fluid milk, according to the Table 1 . The milk composition in general follow this pattern, nonetheless, it's necessary ramify this quantity in the main fatty acids (Table 2). The SFA present in higher quantity on milk is the palmitic (C16:0), which represents round $40 \%$ of the total SFA. Related to the amount of monounsaturated fatty acids (MUFA) and PUFA, the oleic (C18:1) and the linoleic (C18:2) acids are the most representatives. In this 
amount are included the cis and trans fatty acids. The main trans fatty acid of milk is the C18:1 trans-11, called vaccenic acid [7]. Furthermore, it contains quantities of conjugated linoleic acid (CLA), with predominance of the isomer CLA cis-9, trans-11 [8]. However, this fatty acid profile suffers changes associated to many factors, like genetic quality of livestock, stage of lactation, ruminal fermentation or, even, fiber and energy intake and seasonal impacts [9]. This is due to milk fatty acids source, which comes from diet, microbial synthesis, body fat and from the "de novo" synthesis on the mammary gland [10-12].

Table 1: Nutritional composition of fluid milk.

\begin{tabular}{|c|c|}
\hline Nutrient & Amount on milk composition (\%) \\
\hline Water & 87.690 \\
\hline Proteins & 3.280 \\
\hline Carbohydrates (per difference) & 4.650 \\
\hline Total lipids & 3.660 \\
\hline SFA $^{2}$ & 2.278 \\
\hline MUFA $^{3}$ & 1.057 \\
\hline PUFA $^{4}$ & 0.136 \\
\hline Cholesterol & 0.014 \\
\hline
\end{tabular}

Source: USDA National Nutrient Database for Standard Reference [61].

${ }^{1}$ Amount of each nutrient on milk total composition.

${ }^{2}$ Satured fatty acids.

${ }^{3}$ Monounsatured fatty acids.

${ }^{4}$ Polyunsatured fatty acids.

Table 2: Profile of main fatty acids of fluid milk.

\begin{tabular}{|c|c|}
\hline Component & Amount on milk composition (\%) ${ }^{\mathbf{1}}$ \\
\hline SFA $^{2}$ & 2.278 \\
\hline $4: 0$ & 0.119 \\
\hline $6: 0$ & 0.070 \\
\hline $8: 0$ & 0.041 \\
\hline $10: 0$ & 0.092 \\
\hline $12: 0$ & 0.103 \\
\hline $14: 0$ & 0.368 \\
\hline $16: 0$ & 0.963 \\
\hline $18: 0$ & 0.444 \\
\hline MUFA $^{3}$ & 1.057 \\
\hline $16: 1$ & 0.082 \\
\hline $18: 1$ & 0.921 \\
\hline PUFA $^{4}$ & 0.136 \\
\hline $18: 2$ & 0.083 \\
\hline $18: 3$ & 0.053 \\
\hline
\end{tabular}

Adapted from USDA National Nutrient Database for Standard Reference [61].
${ }^{1}$ Amount of each fatty acid on milk total composition (SFA, MUFA or PUFA).

${ }^{2}$ Satured fatty acids.

${ }^{3}$ Monounsatured fatty acids.

${ }^{4}$ Polyunsatured fatty acids.

\section{Fatty Acids Modifications on Rumen}

The rumen has a complex microbiota responsible to digest vegetable components, which large part is indigestible for monogastrics, and for these products provision to the ruminant, that, in turn, it transforms them in foodstuff like milk and beef [13]. In this compartment are present several microorganisms like bacteria, fungi and protozoa. The bacteria are in greater quantity and represents around $95 \%$ of rumen microbiota [14]. Jami \& Mizrahi [13] studied the ruminal bacteria composition of 16 Holstein cows and found that $92.6 \%$ were from Phylum Firmicutes $(41.6 \%)$ and Bacteroidetes (51\%). Other bacteria were found, such as from Phylum Proteobacteria, Actinobacteria and Tenericutes, in proportions of $5.46 \%, 0.86 \%$ and $0.69 \%$, respectively. Another Phylum were grouped and represented $0.37 \%$.

The fungi and protozoa are present in lower amount on rumen, nonetheless, it performs the same important role such as the other microorganisms. The fungi zoospores, after adhering to the particles, it attacks, encyst and germinate on the stomas or fractured sites in the vegetal tissue [15]. Nevertheless, also according to Orpin [15] the protozoa adhere to close particles or engulf and degrade plants fragments which contains chlorophyll and starch granules. The bacteria perform the biohydrogenation of fatty acids on rumen, modifying them in order to convert unsaturated fatty acids in others with lower number of unsaturation [16]. The biohydrogenation occurs in various steps of reduction and numerous bacteria are involved, which the active specie may depend of fatty acid unsaturation degree, but the Butyrivibrio proteoclasticus can convert PUFA directly to SFA [17].

If the feed remains on rumen, a small quantity of fatty acids is absorbed by microorganisms and catabolized in volatile fatty acids (VFA) and $\mathrm{CO}_{2}$, nevertheless, these microorganisms synthetize fatty acids through carbohydrates precursors and hydrogenate unsaturated fatty acids [18]. Thus, as a result of fatty acids modifications caused mainly by ruminal bacteria, the profile ingested by the animal is not the same available for absorption [19]. The unsaturated fatty acids have a short half-life on rumen, because it is quickly hydrogenated to SFA by the microbiota [18]. An amount of 600 to $900 \mathrm{~g} / \mathrm{kg}$ of PUFA are bio hydrogenated and just 1 to $2 \%$ of metabolic hydrogen is used for this purpose [20]. The esterified lipids coming from diet are hydrolyzed to free unsaturated fatty acids, which can be used to synthetize microbial lipids or, through biohydrogenation, turn up to SFA or with lower number of unsaturation (Figure 1). Several enzymes have action in the lipolysis process, such as lipases, galactosidases and phospholipases. In addition, through isomerases and reductases, the compounds are hydrogenated until become SFA [11]. 


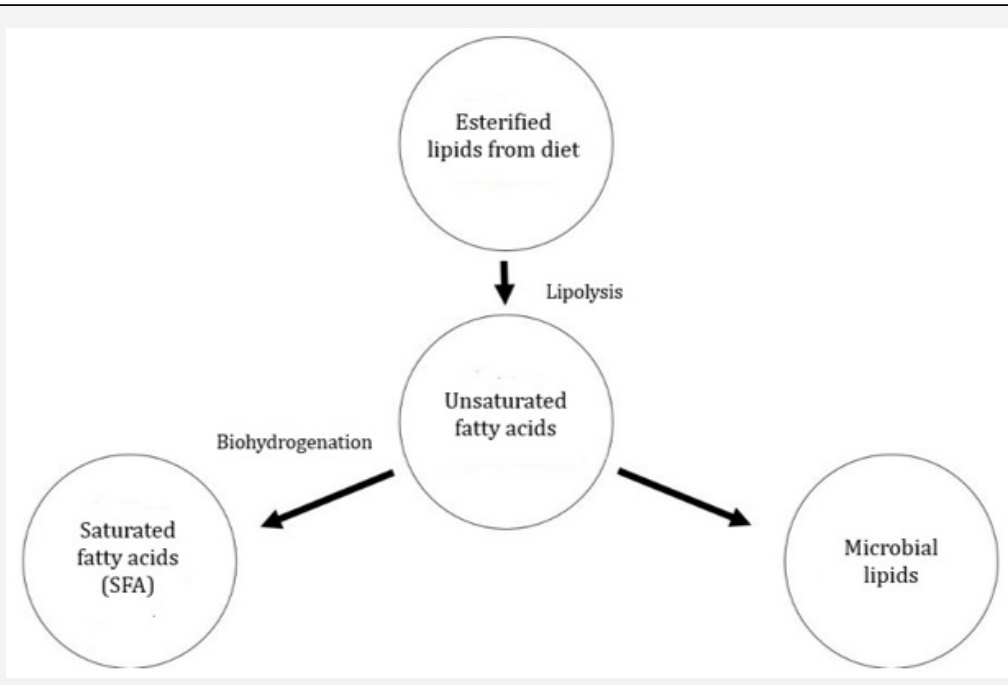

Figure 1: Events on rumen that modify the unsaturated fatty acids [11].

Most of bacteria responsible for the biohydrogenation are cellulolytic and the Butyrivibrio fibrisolvens has greater relevance [18]. Once the effective fiber in the diet is poor, usually as a result of higher concentrates or lower forage particle size, occurs reduction in these bacteria number on rumen and therefore, higher amount of lipids tends to reach the abomasum without suffer hydrogenation $[21,22]$. Other factors also have impact in this passage of unsaturated fatty acids from rumen to abomasum, such as passage rate and quantity of PUFA fed through diet, which can be harmful to some microorganisms. The biohydrogenation is associated to the hypothesis that is a mechanism of detoxification enabling the fiber digestion, because in a certain way, the PUFA are toxic to some cellulolytic bacteria [23]. This toxicity may be linked to the modifications that the PUFA cause on bacteria's cell membrane, as the fatty acids with higher number of unsaturation lead to physical changes on the cells' membranes and, for this reason, can change the cells functions [24].

The microorganisms present in the rumen are important for its substantial capacity of digest and absorb plant material [13]. These are also responsible for changes in the profile and feeds composition of the diet, which lead to the theory that what is ingested by the animal is not the same available for absorption. Thus, the ruminal microorganisms stunt the study of different nutritional handlings and its influence in the final products, once it makes difficult and inaccurate estimate what the animal absorb. An alternative would be comparing these studies with the composition and diversity of the ruminal microbiota, that through equations and analysis of this microorganism's pool, the modifications could be quantified and the final product profile could be estimated with higher accuracy.

\section{Modification of the Millk Fatty Acids Profile}

Several studies aimed the modification of milk fatty acids profile to produce a milk with more desirable attributes for human health [25]. In most cases, there was manipulation of cows' diets, however, some showed that genetic factors also could have influence in this change. Diets composed basically by forages tend to present lower n-6: n-3 ratio. According to Simopoulos [26], ratios of $4: 1$ have positive effect on human health, nevertheless, the desired would be a 2:1 ratio, or even 1:1. The linoleic and $\alpha$-linoleic acids represents, respectively, the fatty acids n- 6 e n-3 more abundant on bovine milk and, therefore, have important influence in the $n-6: n-3$ ratio of this product [25]. While forages are rich in $\alpha$-linoleic acid, cereals like corn and soybean are rich in linoleic acid [27]. Thus, the milk fatty acids composition varies according to the production systems and feed adopted, which animals raised grass-fed are exposed to the forage seasonality, not only in quantity but also in quality [25].

Bainbridge et al. [28] evaluated the effects of different forage species on milk fatty acids of eight Holstein cows. The traits consisted of grazing pear millet (Pennisetum glaucum L.) or grazing mixed winter pastures with more than 15 species. The amount of MUFA and PUFA increased from 2.131 to 2.289 and from 319 to $433 \mathrm{mg} /$ portion of milk with $3.25 \%$ of fat, respectively, comparing the grazing periods of pear millet and mixed winter pastures. Varnold et al. [29] showed similar results, which summer pastures proportioned decreasing of unsaturated fatty acids on beef comparing to animals grazing winter pastures. Besides the evaluation of different forage species on cattle feed, some studies used the supplementation with diverse types of oils and diets with higher PUFA levels to attempt modify the milk fatty acids profile. However, the results obtained were just slight changes, as showed in the studies described below. Santos et al. [30] used four Holstein cows to determine the effects of soybean oil utilization as a source of PUFA and coffee hull as a source of antioxidants in the diet. The production and composition of milk did not differ among traits. The milk fatty acids composition was slightly changed, nevertheless, the inclusion of coffee hull increased the total amount of polyphenols and flavonoids, which resulted on higher antioxidant power and, consequently, greater product stability. 
In another study, Santos et al. [31] fed four Holstein cows with diet containing citrus pulp pellets as a source of antioxidants and soybean oil as a source of PUFA. The control diet was composed by corn silage, ground corn, soybean meal, urea and mineral supplement, which in the other treatments were added soybean oil and/ or citrus pulp pellets. The milk production and concentrations of protein, lactose and urea were similar among traits. In contrast, the milk fat and total solids were higher in the animals fed with the control diet. The animals fed with citrus pulp pellets in the diet presented a milk with greater polyphenols and flavonoids totals, which consequently resulted in increased antioxidant power. The fatty acids composition was barely altered, nevertheless, the cows fed with $18 \%$ of citrus pulp pellets showed higher amount of MUFA and lower of SFA comparing to animals of the other traits.

In order to determine whether this limited alterations in the milk fatty acids profile once cows fed with higher PUFA concentrations is caused by biohydrogenation, the study of Lima et al. [32] was developed, with the purpose to compare the results of PUFA infusion directly on the rumen or abomasum. These authors aimed to clarify the role of rumen microbiota in the transfer of antioxidants from citrus pulp into milk while soybean oil used as a source of PUFA. In this regard, were assigned four fistulated Holstein cows. The treatments were: soybean oil administered in the rumen; soybean oil infused in the abomasum; soybean oil and citrus pulp administered in the rumen; and soybean oil and citrus pulp infused in the abomasum. Cows from treatment with soybean oil infused in the abomasum presented lower proportion of short chain fatty acids and higher amounts of PUFA, n-3 and n- 6 fatty acids in the milk fat. The treatments with administration of citrus pulp in different places showed similar antioxidants properties, which suggest that the rumen microorganisms have small influence in their metabolism. According to the authors, the results of fatty acids infusion in the abomasum can help to determine the by-pass fat level to be assigned for produce a milk with desirable nutritional aspects.

According to Bilal et al. [33], besides the manipulation of animals' diet to alter the milk fatty acids profile, genetic factors also have effect and can be applied to this purpose. For these authors, the heritability estimates and genetic correlations to unsaturation indexes of milk fat indicate that exist genetic variations, so the fatty acids profile more desirable to human health can be reached by genetic selection. Some studies report that milk from different cows breeds present distinctes proportions of SFA and unsaturated fatty acids, which is related to genetic factors [34-36]. Croissant et al. [34] compared milk samples of Holstein and Jersey cows. The milk from Holstein showed higher amounts of long chain fatty acids, MUFA and PUFA, furthermore, lower proportion of SFA comparing to Jersey. This occurred because were paralleled two different genetic groups and due to the influence of this factors have on the animals' metabolism, which consequently have impact in the mammary gland metabolism.

Maurice-van Eijndhoven et al. [35] estimated the difference in the milk fatty acids profile of females Holstein-Friesian, Meuse-
Rhine-Yssel, Dutch-Friesian, Groningen White Headed and Jersey, which are breeds existent on Netherlands. It was used 41,404 samples collected from 24,445 animals. Jersey cows tended to produce higher proportion of SFA, due to the increased amount of C4:0, C6:0, C8:0, C10:0, C12:0, C14:0 and C16:0 comparing to Holstein Friesian, Meuse-Rhine-Yssel and Dutch Friesian. These fatty acids are produced from "de novo" synthesis and the dissimilarity found was related to the distinct milk fat percentage of the breeds. Soyeurt et al. [37] collected data of milk fatty acids and estimated genetic parameters for SFA, MUFA and SFA:unsaturated ratio, besides compare samples from different days in lactation. It was analyzed 100,841 samples from 11,626 primiparous Holstein cows collected between 1991 and 2007. Cows in the first lactation showed milk with lower amount of SFA. Furthermore, the quantity of SFA and the SFA: unsaturated ratio tend to increase until reach the lactation peak and, then, decrease, fact that can be explained due to the occurrence of greater adipose tissue mobilization in the period, which according to Barber et al. [38], is composed in the majority by C16:0 e C18:0. Strong heritability's were reported for SFA and MUFA, both in the beginning and in the end of lactation, however, with some variations.

The great majority of studies that tried to manipulate the milk fatty acids profile kept the focus on the manipulation of the animals' diets. Nonetheless, as a result of the rumen microbiota action and of the animals' physiological mechanisms to form the milk fat in the mammary gland, this modifications barley happens and, because that, a way to alter this profile with greater efficiency and accuracy could be the focus of futures studies. Promising studies in terms of heritability's and positive genetic correlations to select animals with better milk fatty acids profile to human health already exist [39-41]. However, the use of this traits on genetic improvement programs is not frequently yet. Thus, nutritional and genetic strategies should be applied concomitantly.

\section{Fat Formation in the Mammary Gland}

The milk fat is synthetized with fatty acids deriving from the synthesis in the epithelial cells of mammary gland and with long chain fatty acids arising from the bloodstream [42]. This occurs because, in most of the species, the fatty acids produced in the mammary gland have chains no longer than 16 carbons [43]. Fatty acids composed by four to eight carbons are considered short chain, while 10 to 14 are considered medium chain and with more than 16 carbons are considered long chain fatty acids. Short chain fatty acids, medium and a portion of those with 16 carbons are generated in the "de novo" synthesis [44]. This process occurs in the epithelial cells of mammary gland, in which the acetyl-CoA is used to form the malonyl-CoA, reaction catalyzed by the enzyme acetyl-CoA carboxylase and with co-operation of the nicotinamide adenine dinucleotide phosphate (NADPH) in the reduction reactions [43].

Nelson e Cox [45] described that the acetyl-CoA carboxylase contains one biotin molecule and the reaction also depends of one acetyl-CoA molecule and another of bicarbonate $\left(\mathrm{HCO}_{3}^{-}\right)$. The 
bicarbonate carboxyl group is transferred to the biotin through energy cost. The biotin, in turn, acts in the transfer of $\mathrm{CO}_{2}$ to acetyl-CoA, step that result in the formation of malonyl-CoA. The next process is the chain elongation (Figure 2), which all the reactions are catalyzed by the multienzyme complex called fatty acid synthase. The malonyl and acetyl groups of the malonyl-CoA pass through reactions of condensation, reduction, dehydration and reduction again, which results in an acyl group with two more carbons. Thus, begins the formation of one fatty acids chain, in which with reactions that add acetyl groups, can be expanded until the synthesis of palmitic acid with 16 carbons. Nonetheless, the first four carbons of the "de novo" synthesis can be deriving from $\beta$-hydroxybutyrate, compound produced by the ruminal epithelium through the absorbed butyrate [46].

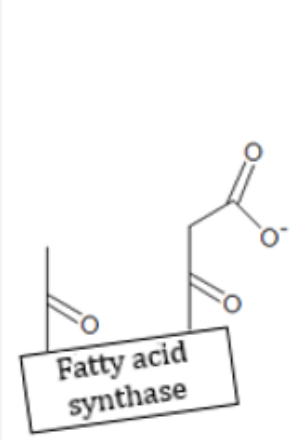

$2 \mathrm{C}$
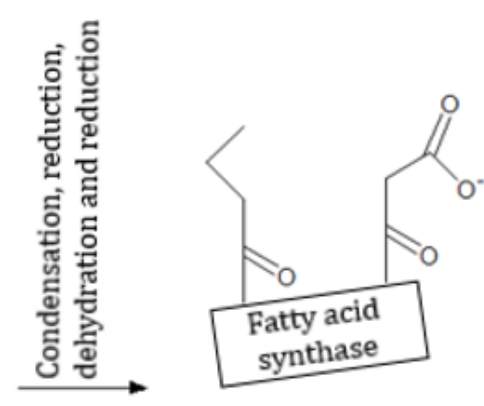

$4 \mathrm{C}$

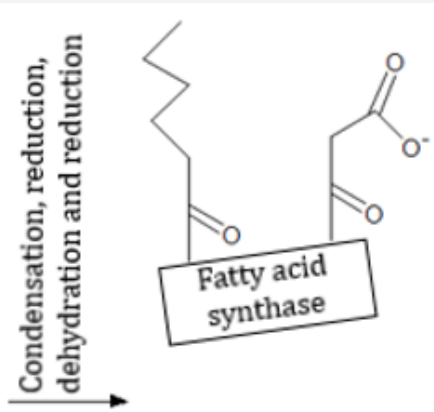

$6 \mathrm{C}$

Figure 2: Fatty acids synthesis process.[45]

Fatty acids with 16 carbons and more than that are derived from animal's bloodstream, however, those with 16 also can be originating from "de novo" synthesis [44]. Furthermore, the serum fatty acids can be originated from diet or be products of adipose tissue mobilization, mechanism that take place with more intensity when the animal is in negative energy balance (NEB).

In addition to the unsaturated fatty acids modifications in the rumen, these are exposed to other alterations in the mammary gland alveoli. In these cells the $\Delta^{9}$-desaturase converts the stearic acid (C18:0) in oleic acid (C18:1) and, due to this role, studies were conducted aiming to increase its activity [5]. This enzyme performances in the production of the main CLA isomer, reaction that the oleic acid C18:1 trans-11 is changed to C18:2 cis-9, cis-12 [47] and it's also contributed to more than $50 \%$ of C18:1 cis-9 secretion on milk [37]. Corl et al. [48] noted that about $80 \%$ of C18:2 cis-9, trans-11 is produced endogenously, in other words, with the desaturase action. Strategies to increase the CLA content on milk are based in raise the vaccenic acid quantity which pass through the rumen and raising the $\Delta^{9}$-desaturase activity [49] (Figure 3). The milk amount of CLA is also affected by physiological factors and variations among animals [50]. Nevertheless, the $\Delta^{9}$-desaturase present negative correlations with the milk fat synthesis [37]. Once it operates in reactions of CLA isomers production, which the CLA trans-9, cis-11 and the CLA trans-10, cis-12 could reduce the fat synthesis, the later in higher magnitude [51].

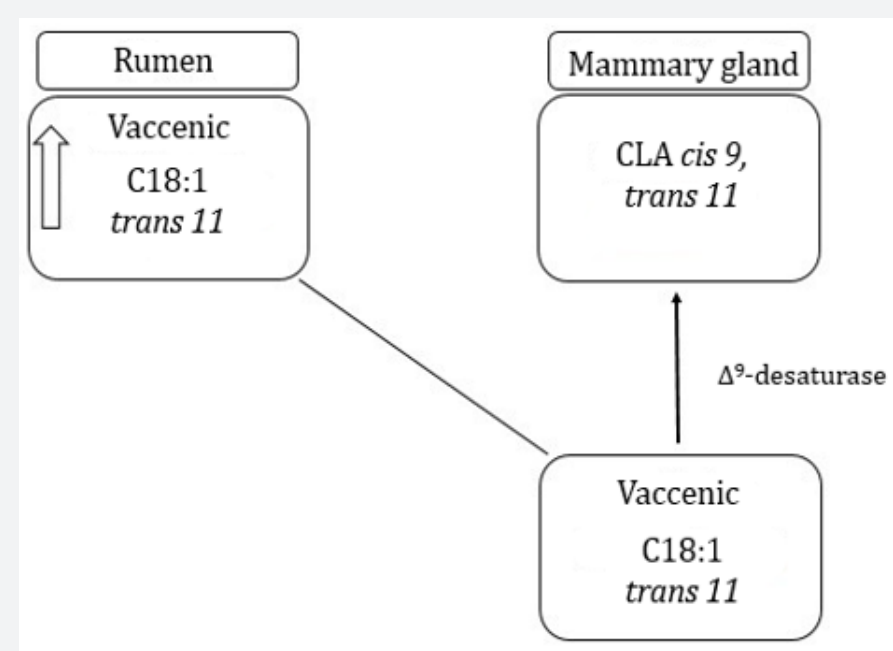

Figure 3: Process of CLA endogenous synthesis in the mammary gland through vaccenic acid.[50] 
Perfield et al. [51] concluded that the increase of CLA trans-9, cis-11 is associated with the milk fat depression (MFD). This conclusion came through the abomasal infusion of $5 \mathrm{~g} /$ day of this isomer in four lactating Holstein cows, which this process reduced in $15 \%$ the fat production, once there is a decrease of lipogenic enzymes expression and the inhibition of fatty acids desaturation [52]. To reach a fatty acids profile considered healthier to human nutrition is inevitable the search for higher numbers of unsaturation in these, however, some isomers in high amounts can impact negatively, causing a decline in the desaturase activity and, consequently, the MFD.

\section{Influence of Fatty Acids Profile on Human Health}

Food with better lipidic profile and, consequently, fatty acids, have beneficial effects on human health. Studies show that the use of PUFA and lower n-6: n-3 ratios on human diets can impact the metabolism and physiological mechanisms, in order to prevent or even assist the diseases treatment [53,54]. Guida et al. [54] showed promising results testing diets with energy restriction and lower PUFA n-6: n-3 ratio. It has positive effect in obese patients with plaque-type psoriasis, which improved the clinic response to pharmacological treatment. The patients were dividing in two groups, which one kept the usual diet and the other had an energy restriction of $20 \mathrm{kcal} / \mathrm{kg} /$ ideal body weight/day and the diet enhanced with an average of $2.6 \mathrm{~g} /$ day with n-3 PUFA. As results, the group submitted to energy restriction, designed to reduce the ingestion of n- 6 PUFA and raise the $n-3$ showed improvement of the metabolic profile and positive effects against the disease. Bell et al. [53] studied the nephrotic range proteinuria, disease characterized by the protein lost in the urine in variable quantity according to the clinical severity, associated to several primary and systemic diseases [55]. The patients were treated for eight weeks with $4 \mathrm{~g} /$ day of omega 3 . The treatment reduced the remaining low-density lipoprotein (LDL) type III as well as the lipoproteins rich in triglycerides. Thus, according to the authors, the patients' potential cardiovascular risk was minimized.

Although the PUFA n- 3 and n- 6 are essential to human beings [56], it excess or the high n-6: n-3 ratio may be harmful to health, along with the trans fatty acids. The trans fatty acids can be produced by both industrial hydrogenation and biohydrogenation, which the latter occurs only in the ruminants and has the CLA cis9, trans-11 as one of the main products [7]. Furthermore, the fatty acids originating from industrial process cause the high-density lipoprotein (HDL) decrease and raise the LDL, which, to a certain extent, can increase the arterial coronary disease risk. The biohydrogenation fatty acids has not clear effects and, for this reason, wanders et al. [7] lead a study with 61 men and women that consumed three diets. One of them was the control and the other two with approximately $20 \mathrm{~g} /$ day of oleic acid originating from industrial hydrogenation or with an 80\% CLA cis-9, trans-11 and 20\% CLA trans-10, cis-12 mix. In healthy volunteers, high intakes of the 80:20 CLA cis-9, trans-11 e 20\% CLA trans-10, cis-12 mix raised the total HDL. Comparing all the individuals, the CLA effect could be considered less detrimental than the industrial trans fatty acids. Therefore, in healthy persons and in the quantity applied in this study, the CLA has positive effects in the serum cholesterol levels.

Other fatty acids deserve attention to human health, because the SFA tend to raise the serum LDL concentrations and, hence, are linked to cardiovascular diseases risk [57]. One of the main SFA sources are the dairy products [58], however, studies have been carried out to produce a milk with better lipidic profile. Organic milks or from cows that had alterations in the diet could have higher n-3 PUFA and a lower n-6: n-3 ratio, on the other hand, it's hard to evaluate the benefits that the different fatty acids profile have on human health [4]. According to Mozaffarian et al. [59], once in a population level, a 5\% change in the diet energy level coming from SFA to PUFA would reduce about $10 \%$ the risk of arterial coronary disease occurrence. Then, FAO \& WHO [60] suggested that some SFA have the effect of raise the LDL serum concentrations, such as, for example, the lauric (C12:0), myristic (C14:0) and palmitic (C16:0) acids. Upon a recommendation of these health organizations, the SFA human consumption could not exceed $10 \%$ of the total energy intake and, if it's possible, the SFA should be replaced by $n-6$ e n-3 PUFA, if this change could reduce the risk of arterial coronary diseases [61].

\section{Conclusion}

Many factors affect the milk fatty acids composition and the knowledge of the interactions between them is limited. Tendencies to manipulate animals genetically and select them to obtain products with desirable specific composition already exist. The market's acceptance to milk with a higher number of unsaturation in the fatty acids profile must be evaluated, once it could be beneficial to human health.

\section{Conflict of Interest}

There is no conflict of Interest.

\section{References}

1. USDA (2017) Food Availability (Per Capita) Data System. United States Department of Agriculture (USDA), USA.

2. FAO (2017) Food Outlook June 2017. Food and Agriculture Organization of the United Nations (FAO), Italy.

3. Yiridoe EK, Bonti-Ankomah S, Martin RC (2005) Comparison of consumer perceptions and preference toward organic versus conventionally produced foods: a review and update of the literature. Renewable Agriculture Food Systems 20: 193-205.

4. Średnicka-Tober D, Barański M, Seal CJ, Sanderson R, Benbrook C, et al. (2016) Higher PUFA and n-3 PUFA, conjugated linoleic acid, $\alpha$-tocopherol and iron, but lower iodine and selenium concentrations in organic milk: a systematic literature review and meta- and redundancy analyses. British Journal of Nutrition 115: 1043-1060.

5. Jenkins TC, Mcguire MA (2006) Major Advances in Nutrition: Impact on Milk Composition. Journal of Dairy Science 89: 1302-1310.

6. Kennelly JJ (1996) The fatty acid composition of milk fat as influenced by feeding oilseeds. Animal Feed Science and Technology 60: 137-152. 
7. Wanders AJ, Brouwer IA, Siebelink E, Katan MB (2010) Effect of a high intake of conjugated linoleic acid on lipoprotein levels in healthy human subjects. Plosone 5: 1-7.

8. Nam IS, Garnsworthy PC (2007) Biohydrogenation of linoleic acid by rumen fungi compared with rumen bacteria. Journal of Applied Microbiology 103: 551-556.

9. Lindmark Månsson H (2008) Fatty acids in bovine milk fat. Food \& Nutrition Research p. 52.

10. Chilliard Y (1993) Dietary fat and adipose tissue metabolism in ruminants, pigs, and rodents: A review. Journal of Dairy Science 76 3897-3931.

11. Jenkins TC (1993) Lipid metabolism in the rumen. Journal of Dairy Science 76: 3851-3863.

12. Parodi P (2004) Milk fat in human nutrition. Australian Journal of Dairy Technology 59: 3-59.

13. Jami E, Mizrahi I (2012) Composition and similarity of bovine rumen microbiota across individual animals. Plosone 7: 1-8.

14. Brulc JM, Antonopoulos DA, Miller ME, wilson MK, Yannarell AC et al. (2009) Gene-centric metagenomics of the fiber-adherent bovine rumen microbiome reveals forage specific glycoside hydrolases National Academy of Sciences, 2009, USA.

15. Orpin GC (1984) The role of ciliate protozoa and fungi in the rumen digestion of plant cell walls. Animal Feed Science and Technology 10: 121-143.

16. LI D, Wang JQ BU DP (2012) Ruminal microbe of biohydrogenation of trans-vaccenic acid to stearic acid in vitro.

17. Wallace RJ, Chaudhary LC, Mckain N, Mcewan NR, Richardson AJ, et al (2006) Clostridium proteoclasticus: a ruminal bacterium that forms stearic acid from linoleic acid. FEMS Microbiology Letters 265: 195201

18. Buccioni A, Decandia M, Minieri S, Molle G, Cabiddu A (2012) Lipid metabolism in the rumen: New insights on lipolysis and biohydrogenation with an emphasis on the role of endogenous plant factors. Animal Feed Science and Technology 174: 1-25.

19. Glasser F, Ferlay A, Doreau M, Schmidely P, Sauvant D et al. (2008) Long-Chain Fatty Acid Metabolism in Dairy Cows: A Meta-Analysis of Milk Fatty Acid Yield in Relation to Duodenal Flows and De Novo Synthesis. Journal of Dairy Science 91: 2771-2785.

20. Czerkawski JW (1984) Microbial fermentation in the rumen. Nutrition Society, United Kingdom.

21. Latham MJ, Storry JE, Sharpe ME (1972) Effect of low roughage diets on the microflora and lipid metabolism in the rumen. Journal of Applied Microbiology 24: 871-877.

22. Loor JJ, Ueda K, Ferlay A, Chilliard Y, Doreau M (2004) Biohydrogenation, duodenum flow and intestinal digestibility of trans fatty acids and conjugated linoleic acids in response to dietary forage: concentrate ratio and linseed oil in dietary cows. Journal of Dairy Science 87: 24722485.

23. Kelly WJ, Leahy SC, Altermann E, Yeoman CJ, Dunne, JC et al. (2010) The Glycobiome of the Rumen Bacterium Butyrivibrio proteoclasticus B316 ${ }^{\mathrm{T}}$ Highlights Adaptation to a Polysaccharide-Rich Environment. Plosone 5(8): e11942.

24. Yang X, Sheng W, Sun GY, Lee JCM (2011) Effects of fatty acid unsaturation numbers on membrane fluidity and $\alpha$-secretasedependent amyloid precursor protein processing. Neurochemistry International 58: 321-329.

25. Schwendel BH, Wester TJ, Morel PCH, Tavandale MH, Deadman C, et al. (2015) Invited review: Organic and conventionally produced milk An evaluation of factors influencing milk composition. Journal of Dairy Science 98: 721-746.
26. Simopoulos AP (2003) Importance of the ratio of $\omega-6 / \omega-3$ essential fatty acids: Evolutionary aspects. World Review of Nutrition and Dietetics 92: 1-22.

27. Khiaosa-ARD R, Klevenhusen F, Soliva CR, Kreuzer M, Leiber F (2010) Transfer of linoleic and linolenic acid from feed to milk in cows fed isoenergetic diets differing in proportion and origin of concentrates and roughages. Journal of Dairy Research 77: 331-336.

28. Bainbridge ML, Egolf E, Barlow JW, Alves JP, Roman J, et al. (2017) Milk from cows grazing on cool-season pastures provides an enhanced profile of bioactive fatty acids compared to those grazed on a monoculture of pearl millet. Food Chemistry 217: 750-755.

29. Varnold KA, Calkins CR, Nuttelman BL, Senaratne-Lenagala LS, Jones TF et al. (2014) Grass type, grazing supplementation, and finishing diets affect beef fatty acids. Nebraska Beef Cattle Reports pp. 804.

30. Santos GT, Schogor ALB, Romero JV, Lima LS (2014) Production, composition, fatty acids profile and stability of milk and blood composition of dairy cows fed high polyunsaturated fatty acids diets and sticky coffee hull. Brazilian Archives of Biology and Technology 57: 493-503.

31. Santos GT, Lima LS, Schogor ALB, Romero JV, Marchi FE, et al. (2014) Citrus pulp as a dietary source of antioxidants for lactating holstein cows fed highly polyunsaturated fatty acid diets. Asian-Australasian Journal of Animal Sciences 27: 1104-1113.

32. Lima LS, Santos GT, Schogor AB, Damasceno JC, Marchi FE, et al. (2014) Effect of abomasal or ruminal supplementation of citrus pulp and soybean oil on nutrient digestibility and ruminal fermentation of dairy cows. Animal Feed Science and Technology 189: 123-129.

33. Bilal G, CUE RI, Mustafa AF, Hayes JF (2012) Short communication: Estimates of heritability's and genetic correlations among milk fatty acid unsaturation indices in Canadian Holsteins. Journal of Dairy Science 95: 7367-7371.

34. Croissant AE, Washburn SP, Dean LL, Drake MA (2007) Chemical Properties and Consumer Perception of Fluid Milk from Conventional and Pasture-Based Production Systems. Journal of Dairy Science 90: 4942-4953.

35. Maurice-van Eijndhoven MHT, Bovenhuis H, Soyeurt H, Calus MPL (2013) Differences in milk fat composition predicted by mid-infrared spectrometry among dairy cattle breeds in the Netherlands. Journal of Dairy Science 96: 1-13.

36. Caroprese M, Mancino R, Ciliberti MG, Di Luccia A, La Gatta B et al. (2017) Fatty acid profile and coagulating ability of milk from Jersey and Friesian cows fed whole flaxseed. Journal of Dairy Research 84: 14-22.

37. Soyeurt H, Dardenne P, Dehareng F, Bastin C, Gengler N (2008) Genetic parameters of saturated and monounsaturated fatty acid content and the ratio of saturated to unsaturated fatty acids in bovine milk. Journal of Dairy Science 91: 3611-3626.

38. Barber MC, Clegg RA, Travers MT, Vernon RG (1997) Lipid metabolism in the lactating mammary gland. Biochimica et Biophysica Acta 1347: 101-126.

39. Bouwman AC, Bovenhuis H, Visker MH, van Arendonk JA (2011) Genome-wide association of milk fatty acids in Dutch dairy cattle. BMC Genetics 12: 43.

40. Krag K, Poulsen NA, Larsen MK, Larsen LB, Janss LL et al. (2013) Genetic parameters for milk fatty acids in Danish Holstein cattle based on SNP markers using a Bayesian approach. BMC Genetics 14: 79.

41. Hein L, Sorensen LP, Kargo M, Buitenhuis AJ (2018) Genetic analysis of predicted fatty acid profiles of milk from Danish Holstein and Danish Jersey cattle populations. Journal of Dairy Science 101: 2148-2157.

42. Palmquist DL, Beaulieu AD, Barbano DM (1993) Feed and animal factors influencing milk fat. Journal of Dairy Science 76: 1753-1771. 
43. Dils RR (1986) Comparative aspects of milk fat synthesis. Journal of Dairy Science 69: 904-910.

44. Bauman DE, Griinari JM (2003) Nutritional regulation of milk fat synthesis. Annual Review of Nutrition 23: 203-227.

45. Nelson DL, Cox M (2002) Lehninger - Princípios de Bioquímica. (3 ${ }^{\text {rd }}$ edn), Sarvier, São Paulo, Brazil, pp. 599-638.

46. Emery RS (1988) Milk fat depression and the influence of diet on milk composition. Veterinary Clinics of North America: Food Animal Practice 4: 289-305.

47. Bauman DE, Baumgard LH, Corl BA, Griinari JM (1999) Biosynthesis of conjugated linoleic acid in ruminants. Proceedings of the American Society of Animal Science: 1-11.

48. Corl BA, Baumgard LH, Dwyer DA, Griinari JM, Phillips BS et al. (2001) The role of 9-desaturase in the production of cis-9, trans-11 CLA Journal of Nutritional Biochemistry 12: 622-630.

49. Bauman DE, Lock AL (2010) Milk fatty acid composition: challenges and opportunities related to human health. World Buiatrics Congress, Chile, USA.

50. Bauman DE, Lock AL (2006) Conjugated linoleic acid: Biosynthesis and nutritional significance. In: FOX PF, Mc Sweeney PLH, Advance Dairy Chemistry, Springer, New York, USA, 93-136.

51. Perfield JW, Lock, AL, Griinari JM, Sæbø A, Delmonte P et al. (2007) Trans-9, Cis-11 Conjugated Linoleic Acid Reduces Milk Fat Synthesis in Lactating Dairy Cows. Journal of Dairy Science 90: 2211-2218.

52. Gervais R, Mcfadden JW, Lengi AJ, Corl BA, Chouinard PY (2009) Effects of intravenous infusion of trans-10, cis-12 18:2 on mammary lipid metabolism in lactating dairy cows. Journal of Dairy Science 92 5167-5177.
53. Bell S, Cooney J, Packard CJ, Caslake MJ, Deighan CJ (2012) The effect of Omega-3 fatty acids on the atherogenic lipoprotein phenotype in patients with nephrotic range proteinuria. Clinical Nephrology 77: 445-453.

54. Guida B, Napoleone A, Trio R, Nastasi A, Balato N et al. (2014) Energyrestricted, n-3 polyunsaturated fatty acids-rich diet improves the clinical response to immuno-modulating drugs in obese patients with plaque-type psoriasis: A randomized control clinical trial. Clinical Nutrition 33: 399-405.

55. LeeYH, Kim K, Kim YG, Monn JY, Jung SW et al. (2017) Clinicopathological features of diabetic and nondiabetic renal diseases in type 2 diabetic patients with nephrotic-range proteinuria. Medicine 36: 1-7.

56. Russo GL (2009) Dietary $n-6$ and $n-3$ polyunsaturated fatty acids: From biochemistry to clinical implications in cardiovascular prevention. Biochemical Pharmacology 77: 937-946.

57. Siri-Tarino PW, Sun Q, Hu FB, Krauss RM (2010) Saturated fat, carbohydrate, and cardiovascular disease. American Journal of Clinincal Nutrition 91: 502-509.

58. HHS (2005) Dietary guidelines for Americans. United States Department of Health \& Human Services (HHS), USA.

59. Mozaffarian D, Micha R, Wallace S (2010) Effects on coronary heart disease of increasing polyunsaturated fat in place of saturated fat: A systematic review and meta-analysis of randomized controlled trials. Plos Medicine p. 7.

60. FAO, WHO (2010) Interim summary of conclusions and dietary recommendations on total fat \& fatty acids. Italy, Food and Agriculture Organization of the United Nations (FAO), Switzerland, World Health Organization (WHO).

61. USDA (2016) USDA National Nutrient Database for Standard Reference, United States Department of Agriculture (USDA), USA.

Your next submission with Juniper Publishers
will reach you the below assets
- Quality Editorial service
- Swift Peer Review
- Reprints availability
- E-prints Service
- Manuscript Podcast for convenient understanding
- Global attainment for your research
- Manuscript accessibility in different formats
( Pdf, E-pub, Full Text, Audio)
- Unceasing customer service
Track the below URL for one-step submission
https://juniperpublishers.com/online-submission.php

